\title{
Evaluation of Monocyte Chemoattractant Protein 1(MCP-1)as a Predictor of Complications in Type 2 Diabetes Mellitus in Zagazig University Hospital
}

\author{
Amira A. Mahmoud ${ }^{1}$, Mohamed Said Soliman', Azza Moustafa ${ }^{2}$
}

Departments of ${ }^{1}$ Internal Medicine and ${ }^{2}$ Clinical Pathology, Faculty of Medicine, Zagazig University, Egypt.

Corresponding author: Amira A. Mahmoud, Mobile: (+20) 01007257223, Email amiraahmed923@gmail.com

\begin{abstract}
Background: Monocyte chemoattractant protein-1 (MCP-1) is the first discovered and most extensively studied chemotactic cytokines $(\mathrm{CC}=$ chemokine $)$. Many studies on its role in the etiologies of obesity- and diabetes-related diseases have been increased exponentially during the past two decades. MCP-1, a chemokine involved in monocyte chemotaxis can be consistently found at high levels in the patients with type 2 diabetes mellitus. MCP1 may be an early predictor of complications of diabetes.

Objective: Assessment of the levels of MCP-1 and other biochemical markers in diabetic subjects compared to a healthy group, which in turn can be beneficial to clarify the correlations of MCP-1 levels in diabetes mellitus with other clinical and biochemical parameters.

Patients and methods: Eighty-one participants including both male and female, of cross-matched ages ranging between $30-60$ years old were included in this study. They were divided into three equal groups: group I (control group), group II (recently diagnosed T2DM) and group III (old diagnosed T2DM more than 10 years).

Results: The highest level of MCP-1 was found in the old diagnosed diabetic group while the lowest level was found in the non-diabetic control group. The LSD statistical analysis showed there was significant difference between all groups of the study. Our results showed that serum MCP-1 was elevated in cases of the group 3 (old diagnosed diabetic patients) who were suffering from diabetic nephropathy (9/27), diabetic retinopathy (9/27) and the last 9/27 were suffering of neuropathy.
\end{abstract}

Conclusion: The MCP-1 level is increased in type 2 Diabetic patients and significantly increased with the progression of diabetes complications as diabetic retinopathy, diabetic nephropathy and diabetic neuropathy.

Keywords: MCP-1, T2DM.

\section{INTRODUCTION}

The prevalence of type 2 diabetes worldwide is increasing rapidly in association with the increase in obesity. Complications are a major fear of patients with diabetes. Complications of diabetes affect many tissues and organs, causing microvascular complications such as triopathy (retinopathy, nephropathy, and neuropathy) and macrovascular complications such as cardiovascular diseases, peripheral vascular diseases and stroke ${ }^{(\mathbf{1})}$.

MCP-1, a key chemokine involved in monocyte chemotaxis can be consistently found at high levels in the patients with type 2 diabetes mellitus. Moreover, MCP-1 levels decline with treatment and control of diabetes mellitus ${ }^{(2)}$. It is implicated in the pathogenesis of numerous complications of diabetes ${ }^{(3)}$. It exhibits most potent chemotactic activity toward monocytes, and it is suggested to be implicated in the development and progression of diabetic nephropathy by playing a role in infiltration of monocyte/ macrophage ${ }^{(4)}$.

MCP-1 is critical for the initiation and development of atherosclerotic lesions. During the progression of atherosclerosis. There is an accumulation of low-density lipoprotein (LDL) within macrophages and monocytes present in the intimal layer. Deposition of lipids within these cells leads to the formation and eventual enlargement of atherosclerotic lesions. Gun-fed a high cholesterol diet to mice deficient in LDL that also expressed either wild type
MCP-1 or were MCP-1-deficient. The LDL-/MCP-1deficient mice deposited less lipids and had fewer macrophages present within their aortic walls ${ }^{(\mathbf{5})}$.

Chemokines (chemotactic cytokines) are small heparin-binding proteins, which direct migration of circulating leukocytes to sites of inflammation or injury (). The largest family is the CC chemokine MCP-1. Two residues of MCP 1, out of four conserved cysteine residues are thoroughly characterized $\mathrm{CC}$ chemokine. MCP-1 (monocyte chemo-attractant protein 1), also known as CCL2 - a potent agonist for monocytes, memory $\mathrm{T}$ cells and basophils intimal hyperplasia after angioplasty, as well as in vasculogenesis and thrombosis. MCP-1 is also expressed and secreted by adipocytes, which has been reported to be involved in the recruitment and activation of peripheral blood leukocytes in adipose tissue and in the induction of systemic insulin resistance ${ }^{(7)}$. Hyperglycemia is the major cause of diabetic angiopathy. High glucose treatment on endothelial cells isolated from diabetic subjects resulted in a $40-70 \%$ increase of MCP-1 release, and a 10-20\% increase of the basal expression of vascular cell adhesion molecule-1 (VCAM-1), indicating synergistic enhancement on the monocyteendothelial cell interaction ${ }^{(5)}$.

A vitro study demonstrated that advanced glycation end-products; high glucose concentration, glycated albumin and glycoxidized LDL enhanced MCP-1 expression in human endothelial cells ${ }^{(8)}$.

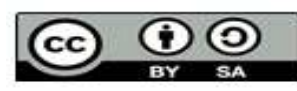

This article is an open access article distributed under the terms and conditions of the Creative Commons Attribution (CC BY-SA) license (http://creativecommons.org/licenses/by/4.0/) 
Similarly, high glucose treatment on human aortic smooth muscle cells (SMC) unregulated the expression of MCP-1 and fractalkine leading to increased monocyte-SMC adhesive interactions by a mechanism involving activation of MAPK, AP-1 and $\mathrm{NFKB}{ }^{(9)}$. Consistent with previous reports, exposure of human endothelial ECV304 cells to high glucose for $24 \mathrm{~h}$ caused an increase of MCP-1 and intercellular adhesion molecule-1 (ICAM-1), and promoted cell adhesion between monocyte and ECV304 cells ${ }^{\mathbf{( 1 0})}$. Furthermore, high glucose treatment on human acute monocytic leukemia THP-1 cells increased both mRNA and protein levels of MCP-1, enhanced the adhesion of THP-1 cells to endothelial cells, and the pathways reportedly involved in oxidative stress and protein kinase $\mathrm{C}^{(\mathbf{1 1})}$.

Obesity is a result of expansion in both number and size of adipocytes. The gene expression of CC chemokines and their receptors (such as MCP-1 and CCR2) was found higher in the visceral and subcutaneous adipose tissues of obese patients compared to lean controls ${ }^{(\mathbf{1 2})}$. Furthermore, MCP-1 protein expression was higher in omental fat than in subcutaneous fat in severely obese patients, which was paralleled by elevated macrophage infiltration into omental fat ${ }^{(13)}$. The plasma level of MCP-1 has been generally found to be increased in obese adults ${ }^{(14)}$ and obese children (15) compared to lean controls. It correlated with the number and volume of omental adipocytes in baboos ${ }^{(\mathbf{1 6})}$, and was similarly affected by visceral adiposity in human ${ }^{(\mathbf{1 7})}$.

The present study aimed to assess the levels of MCP-1 and other biochemical markers in diabetic subjects compared to a healthy group, which in turn can be beneficial to clarify the correlations of MCP-1 levels in diabetes mellitus with other clinical and biochemical parameters.

\section{SUBJECTS AND METHODS}

This is a, comparative case-control study that was conducted in Internal Medicine and Clinical Pathology Departments, Zagazig University in the period from January 2017 to April 2019. Eighty-one participants including both male and female, of cross-matched ages ranging between $30-60$ years old were included in this study and were divided into three equal groups:

- Group I: Included 27 non diabetic participants (16 males and 11 females).

- Group II: Included 27 recently diagnosed diabetic participants (18 males and 9 females).

- Group III: Included 27 old diagnosed diabetic participants $\geq 10$ years (16 males and 11 females).

\footnotetext{
Ethical approval and written informed consent: An approval of the study was obtained from Zagazig University academic and ethical
}

committee. Every patient signed an informed written consent for acceptance of the operation.

Exclusion criteria: Any general medical disease other than diabetes mellitus that may affect the general condition of the patients "e.g. chronic liver disease, malignancies, any connective tissue disorders, endstage chronic kidney failure and advanced heart failure. In addition, chronic obstructive pulmonary disease, cancer, HIV, impaired consciousness, previous treatment with immunosuppressive drugs, chemotherapy or radiotherapy, patients taking antioxidants "affects level of cytokines", smokers, and also patients who refused to complete the study. Patients with concurrent acute illnesses, medical history of clinical cardiovascular disease; medical history of diseases like hypertension, rheumatoid arthritis, anemia and bronchial asthma. Moreover, medications like warfarin, acetylsalicylic acid, alphamethyldopa, vitamins, tramadol and simvastatin that interfered with $\mathrm{HbAlc} \%$ measurements and smoking history were excluded from the study. Clinical examination was done to exclude any hidden medical problems e.g. chronic liver diseases or coronary heart disease. Fundus examination for diagnosis of retinopathy and sensory and motor examination for neuropathy.

The anthropometric measurements and blood pressure were recorded. Biochemical testing included plasma fasting blood glucose, lipid profile, creatinine and albumin were done on Cobas 8000 (c702 module) and glycated hemoglobin ( $\mathrm{HbA} 1 \mathrm{c} \%)$ were measured by by immunoturbidimetric inhibition on Cobas (c501 module). Lipid profile and albumin/creatinine ratio "ACR" were estimated. A random urine sample was collected and albumin and creatinine were measured, then the ACR was calculated by the following equation: $\mathrm{ACR}=$ Albumin/creatinine. The equation takes albumin in $\mathrm{g} / \mathrm{dL}$ and creatinine in $\mathrm{mg} / \mathrm{dL}$ and the results were categorized according to the following:

1. ACR $<10 \mathrm{mg} / \mathrm{g}(<1 \mathrm{mg} / \mathrm{mmol})$ is considered normal.

2. ACR $10-30 \mathrm{mg} / \mathrm{g}(1-3 \mathrm{mg} / \mathrm{mmol})$ is considered high normal.

3. ACR $>2200 \mathrm{mg} / \mathrm{g}(>220 \mathrm{mg} / \mathrm{mmol})$ is considered nephrotic range.

Body Mass Index (BMI): Body weight and height were measured in participants wearing a hospital gown and without shoes. BMI was measured by dividing weight in kilogram over square of height in meters. The WHO regards a BMI of less than 18.5 as underweight and may indicate malnutrition, an eating disorder, or other health problems, while a BMI greater than 25 is considered overweight and above 30 is considered obese $^{(\mathbf{1 8 )} \text {. }}$

Quantitative measurement of MCP-1 in serum was carried out using a sensitive competitive ELISA (Elabscience Biotechnology Co. Japan). 
The anthropometric measurements and blood pressure were recorded. Biochemical testing included plasma fasting blood glucose(LABKIT, Spain), HbA1c $\%$ (Human Co., German), MCP-1(Elabscience Biotechnology Co., Japan), TGF ((DRG diagnostics Company, Germany). insulin (Demedetec Company, Germany) were detected by enzyme-linked immunosorbent (ELISA).

\section{Statistical analysis}

Data were collected in a master sheet, coded, entered and analyzed using IBM-SPSS version 23. The significance of different means (quantitative data) was tested using Students-t-test or ANOVA test. The significance of different percentages (qualitative data) was tested using Pearson Chi-square test ( $\chi 2$-test) with application of Yate's correction or Fisher Exact test whenever applicable. Statistical significance was considered whenever the $\mathrm{P}$ value for the test of significance was equal or less than 0.05 .

\section{RESULTS}

Table (1): The comparison of demographic and laboratory data of the three studied groups

\begin{tabular}{|c|c|c|c|c|c|c|c|}
\hline Variable & \multicolumn{2}{|c|}{$\begin{array}{c}\text { Group I } \\
\text { (control) } \\
(\mathbf{n}=\mathbf{2 7}) \\
\end{array}$} & \multicolumn{2}{|c|}{$\begin{array}{c}\text { Group II } \\
\text { (recent DM) } \\
(\mathbf{n}=\mathbf{2 7}) \\
\end{array}$} & \multicolumn{2}{|c|}{$\begin{array}{c}\text { Group III } \\
\text { (old DM) } \\
(\mathbf{n}=\mathbf{2 7}) \\
\end{array}$} & $\mathbf{P}$ \\
\hline $\begin{array}{l}\text { Age: (years) } \\
\text { Mean } \pm \text { SD } \\
\text { Range }\end{array}$ & & \multicolumn{2}{|c|}{$\begin{array}{l}47.07 \pm 4.77 \\
39-55\end{array}$} & \multicolumn{2}{|c|}{$\begin{array}{c}49.48 \pm 3.55 \\
45-59\end{array}$} & 0.068 \\
\hline $\begin{array}{l}\text { Duration: (years) } \\
\text { Mean } \pm \text { SD }\end{array}$ & \multicolumn{2}{|c|}{$40-56$} & \multicolumn{2}{|c|}{$\begin{array}{l}\text { Less } \\
\text { than } 1 \text { year }\end{array}$} & \multicolumn{2}{|c|}{$15.04 \pm 2.94$} & \\
\hline \multirow[t]{2}{*}{ BMI: $\left(\mathbf{K g} / \mathbf{m}^{2}\right)$ Mean \pm SD } & \multicolumn{2}{|c|}{$22.29 \pm 1.98$} & \multicolumn{2}{|c|}{$26.19 \pm 2.62$} & \multicolumn{2}{|c|}{$28.26 \pm 4.04$} & $<0.001$ \\
\hline & No & $\%$ & No & $\%$ & No & $\%$ & $\mathbf{P}$ \\
\hline $\begin{array}{l}\text { Sex: } \\
\text { Female } \\
\text { Male }\end{array}$ & $\begin{array}{l}11 \\
16\end{array}$ & $\begin{array}{l}40.7 \\
59.3\end{array}$ & $\begin{array}{c}18 \\
9\end{array}$ & $\begin{array}{l}66.7 \\
33.3\end{array}$ & $\begin{array}{l}11 \\
16\end{array}$ & $\begin{array}{l}40.7 \\
59.3\end{array}$ & 0.09 \\
\hline $\begin{array}{l}\text { Hypertension: } \\
\text { No } \\
\text { Yes }\end{array}$ & $\begin{array}{c}27 \\
0\end{array}$ & $\begin{array}{c}100 \\
0\end{array}$ & $\begin{array}{l}16 \\
11\end{array}$ & $\begin{array}{l}59.3 \\
40.7\end{array}$ & $\begin{array}{l}13 \\
14\end{array}$ & $\begin{array}{l}48.1 \\
51.9\end{array}$ & $<0.001$ \\
\hline FBS: $(\mathbf{m g} / \mathrm{dl})$ Mean \pm SD & \multicolumn{2}{|c|}{$88.59 \pm 10.83$} & \multicolumn{2}{|c|}{$192.48 \pm 37.64$} & \multicolumn{2}{|c|}{$233.07 \pm 17.95$} & $<0.001$ \\
\hline Cholesterol: (mg/dl) Mean \pm SD & \multicolumn{2}{|c|}{$139.63 \pm 7.84$} & \multicolumn{2}{|c|}{$259.48 \pm 32.87$} & \multicolumn{2}{|c|}{$260.56 \pm 33.32$} & $<0.001$ \\
\hline TG: (mg/dl) Mean \pm SD & \multicolumn{2}{|c|}{$82.15 \pm 6.6$} & \multicolumn{2}{|c|}{$252.41 \pm 39.82$} & \multicolumn{2}{|c|}{$263.33 \pm 6.51$} & $<0.001$ \\
\hline HDL: $(\mathbf{m g} / \mathbf{d l})$ Mean \pm SD & \multicolumn{2}{|c|}{$51.67 \pm 9.91$} & \multicolumn{2}{|c|}{$34.78 \pm 6.59$} & \multicolumn{2}{|c|}{$31.33 \pm 6.64$} & 0.004 \\
\hline LDL: (mg/dl) Mean \pm SD & \multicolumn{2}{|c|}{$124.48 \pm 11.14$} & \multicolumn{2}{|c|}{$248.81 \pm 31.6$} & \multicolumn{2}{|c|}{$260.3 \pm 25.11$} & $<0.001$ \\
\hline $\begin{array}{l}\text { Protein urine: Mean } \pm \text { SD } \\
\text { Median }\end{array}$ & \multicolumn{2}{|c|}{$\begin{array}{c}0.41 \pm 0.19 \\
0.35\end{array}$} & \multicolumn{2}{|c|}{$\begin{array}{c}0.49 \pm 0.04 \\
0.41\end{array}$} & \multicolumn{2}{|c|}{$\begin{array}{c}0.98 \pm 0.03 \\
0.5\end{array}$} & $\mathbf{0 . 0 3}$ \\
\hline $\begin{array}{l}\text { Creatinine: }(\mathbf{m g} / \mathbf{d l}) \\
\text { Mean } \pm \text { SD } \\
\text { Median }\end{array}$ & \multicolumn{2}{|c|}{$\begin{array}{l}0.69 \pm 0.01 \\
0.68\end{array}$} & \multicolumn{2}{|c|}{$\begin{array}{l}0.7 \pm 0.05 \\
0.7\end{array}$} & \multicolumn{2}{|c|}{$\begin{array}{c}1.09 \pm 0.06 \\
0.7\end{array}$} & 0.024 \\
\hline HbA1c: (\%) Mean \pm SD & \multicolumn{2}{|c|}{$5.7 \pm 1.2$} & 7.79 & $\overline{0.77}$ & & \pm 0.90 & $0.02 *$ \\
\hline MCP-1: (pg/ml) Mean \pm SD & 130.8 & \pm 4.78 & 225.1 & 1.43 & $\overline{268}$ & \pm 1.95 & $<0.001 * *$ \\
\hline
\end{tabular}

Groups with different letters are statistically significant $(\mathrm{P}<0.05)$

Table (2): LSD different clinical and laboratory parameters
Table (1) showed that there were statistical significance differences between the three studied groups in BMI. The difference was found between all groups. No difference was found between studied groups in age and sex distribution. This table also showed that the duration of DM among group II is less than 1 years and in Group III, ranged from 10 to 19 years with a mean of $15.04 \pm 2.94$ years. Regarding hypertension, there were statistical significance differences between control and the two cases groups in frequency of HTN.

In addition, there were statistical significant differences between the three studied groups in FBS level. Regarding lipid profile, there were statistical significance differences between the control group and both of cases groups. In protein in urine and creatinine level, the difference was found between group III and both of group I and group II. Besides, there were statistical significance difference between group II and group III in HbA1c level. Lastly, there was statistical significance difference between the three studied groups in MCP level. 


\begin{tabular}{|c|c|c|c|}
\hline Parameters & Diabetics & old Diabetics & Diabetics \\
\hline BMI & $<0.001$ & $<0.001$ & $<\mathbf{0 . 0 3 0}$ \\
\hline Cholesterol & $<0.001$ & $<0.001$ & 0.905 \\
\hline TG & $<0.001$ & $<0.001$ & 0.358 \\
\hline HDL & $<0.001$ & $<0.001$ & 0.061 \\
\hline LDL & $<0.001$ & $<0.001$ & 0.145 \\
\hline Proteinuria & 0.180 & 0.003 & 0.011 \\
\hline Creatinine & 0.774 & 0.034 & 0.043 \\
\hline MCP-1 & $<0.001$ & $<0.001$ & $<0.001$ \\
\hline
\end{tabular}

Table (2) showed that there were positive significant correlations between MCP and FBS and HBA1c in Both Group II \& III. In addition, there were positive significant correlation, between MCP and BMI in Group II and between MCP and both cholesterol and TG in Group III.

Table (3): Correlation between MCP and age, BMI, duration and laboratory findings of the three studied groups

\begin{tabular}{|c|c|c|c|c|c|c|}
\hline \multirow{3}{*}{ Variable } & \multicolumn{6}{|c|}{ MCP } \\
\hline & \multicolumn{2}{|c|}{$\begin{array}{c}\text { Group I } \\
\text { (control) }(n=27)\end{array}$} & \multicolumn{2}{|c|}{$\begin{array}{c}\text { Group II } \\
\text { (recent DM) }(\mathrm{n}=27)\end{array}$} & \multicolumn{2}{|c|}{$\begin{array}{c}\text { Group III } \\
\text { (old DM) }(n=27)\end{array}$} \\
\hline & $\mathbf{r}$ & $\mathbf{P}$ & $\mathbf{r}$ & $\mathbf{P}$ & $\mathbf{r}$ & $\mathbf{P}$ \\
\hline Age (year) & 0.04 & 0.83 & 0.29 & 0.14 & 0.16 & 0.43 \\
\hline BMI $\left(\mathrm{Kg} / \mathrm{m}^{2}\right)$ & 0.20 & 0.31 & 0.32 & $0.11 \mathrm{NS}$ & 0.57 & $0.002 * *$ \\
\hline Duration (years) & - & -- & --- & $-\cdots$ & 0.15 & 0.45 \\
\hline FBS: $(\mathrm{mg} / \mathrm{dl})$ & 0.05 & 0.80 & 0.54 & 0.004 & 0.67 & $<0.001 * *$ \\
\hline Cholesterol (mg/dl) & 0.14 & 0.50 & 0.36 & 0.04 & 0.45 & 0.02 \\
\hline TG (mg/dl) & 0.08 & 0.70 & 0.38 & 0.04 & 0.41 & 0.03 \\
\hline HDL (mg/dl) & -0.30 & 0.13 & -0.41 & 0.03 & -0.39 & 0.03 \\
\hline LDL (mg/dl) & 0.28 & 0.16 & 0.39 & 0.04 & 0.42 & 0.02 \\
\hline Protein in urine & 0.10 & 0.62 & 0.11 & 0.57 & 0.03 & 0.87 \\
\hline Creatinine (mg/dl) & 0.34 & 0.09 & 0.15 & 0.46 & 0.22 & 0.28 \\
\hline HbA1c (\%) & -- & --- & 0.47 & 0.01 & 0.88 & $<0.001$ \\
\hline
\end{tabular}

Serum MCP-1 was elevated in cases of the 3rd group " old diagnosed diabetic patients" who was known to be suffering of diabetes complications where 9/27 were suffering of diabetic nephropathy, 9/27 were suffering of diabetic retinopathy and the last 9/27 were suffering of neuropathy (Table 3).

Table (4): Classification of group III (old DM group)

\begin{tabular}{|l|c|c|}
\hline \multicolumn{1}{|c|}{ Variable } & \multicolumn{2}{c|}{ Group III (Old DM) (n=27) } \\
\cline { 2 - 3 } & No & \% \\
\hline Classification: & & \\
Neuropathy & 9 & 33.3 \\
Nephropathy & 9 & 33.3 \\
Retinopathy & 9 & 33.3 \\
\hline
\end{tabular}

There were no statistical significance differences between cases that had neuropathy, cases that had nephropathy and cases that had retinopathy in MCP level (Table 4).

Table (5): Comparison of MCP in Group III

\begin{tabular}{|l|c|c|c|c|}
\hline Variable & $\begin{array}{c}\text { Group III a } \\
(\text { Neuropathy }) \\
(\mathbf{n = 9})\end{array}$ & $\begin{array}{c}\text { Group III b } \\
(\text { Nephropathy }) \\
(\mathbf{n = 2 7})\end{array}$ & $\begin{array}{c}\text { Group III c } \\
(\text { Retinopathy }) \\
(\mathbf{n = 2 7})\end{array}$ & P \\
\hline $\begin{array}{l}\text { MCP (pg/ml) } \\
\text { Mean } \pm \text { SD }\end{array}$ & $267.98 \pm 1.9$ & $268 \pm 1.96$ & $268.74 \pm 2.12$ & 0.67 \\
\hline
\end{tabular}

Regarding MCP-1 in group III, there was no significant difference between patients in this group.

DISCUSSION

As regard Hypertension, our results showed that there was a statistical significant difference between the three studied groups with higher 
incidence of HTN in the two diabetic groups compared to the non- diabetics. These results go in harmony with the results of the study done by Tilak et al. ${ }^{(19)}$ where 64 (male: female; 40:24) type 2 diabetic subjects were divided into three groups based on their renal function and were compared with non-diabetic controls $[\mathrm{n}=20$ (Male: Female; 13:7)]. They found that the incidence of HTN when compared to the control non- diabetics group were $31.2 \%, 65.2 \%, 84 \%$ Vs $0 \%$ with p-value: 0.003 .

Our results showed that there were statistical significant difference between the three groups as regards serum cholesterol, serum TG, LDL, and HDL. LSD statistical analysis of these results was done and showed that serum cholesterol level in both diabetic groups was higher than in the non-diabetic group. In addition, LSD showed that serum triglyceride level was higher in the two diabetic groups was higher than in the non-diabetic group. As regard LDL, we found that it was higher in the two diabetic groups than in the non-diabetic control group. On the reverse, HDL was found to be higher in the non-diabetic control group than in the two diabetic groups. The LSD statistical analysis showed that there were no statistical significant difference between the old and recently diagnosed diabetic groups as regards serum cholesterol, triglycerides, LDL and HDL. These results go in similarity with Agrawal et al. ${ }^{(20)}$ who found in their study, which included 400 participants (200 were Urban and 200 were rural) that there was a significant change in FBS, lipids, and atherogenic lipid risk factors among urban and rural diabetic patients.Lipids, such as TC, TG, and VLDL, were significantly $(\mathbf{p}<\mathbf{0 . 0 5})$ increased with a non- significant rise in LDL in both categories of diabetic patients compared to their respective control population. All these variables were not significantly different between the two diabetic groups. The HDL level was found to be decreased in both diabetic groups versus their respective controls.

A significant positive correlations in both diabetic "recent and old diagnosed" groups were found between the MCP-1 and total cholesterol, triglycerides and LDL, while a significant negative correlation was found between the MCP-1 and HDL. This result is in agreement with Wang and Chen ${ }^{(21)}$ who reported that they found that the level of MCP-1 was positively correlated with LDL-C and TC $(r=322, P=005 ; r=333$; $\mathbf{P}=003$, respectively) and the correlation was statistically significant. Although a tendency of positive correlations between MCP-1 and TG was found $(\mathbf{r}=\mathbf{1 8 4}, \mathbf{P}=\mathbf{1 1 1})$, a negative correlation between MCP-1 and HDL-C was also found $(\mathbf{r}=\mathbf{- 0 . 1 7 5}$, $\mathbf{P}=\mathbf{0 . 1 3 0}$ ) and the correlation did not achieve statistical significance.

As regards proteinuria and serum creatinine level, our result showed that there was a statistical significant difference between the three groups of the study. LSD statistical analysis showed that the old diagnosed group had higher level of proteinuria and serum creatinine than the recently diagnosed diabetic group and non-diabetic control group. This can be easily explained by that the old diagnosed diabetic group included some patients who were complicated by diabetic nephropathy.

As regards serum MCP-1, our results showed there was a statistical significant difference between the three studied groups. These results are in harmony with Tilak et $\boldsymbol{a l} .{ }^{(\mathbf{1 9})}$ who found in their study that mean levels of MCP-1 in subjects with type 2 diabetes were significantly higher than those in the control group $(\mathbf{p}<\mathbf{0 . 0 5})$. The levels of MCP-1 were higher in patients with proteinuria as compared with normo-albuminuria $(\mathbf{p}<\mathbf{0 . 0 5})$, microalbuminuria $(\mathbf{p}=$ $\mathbf{0 . 0 7})$ and healthy controls $(\mathbf{p}<\mathbf{0 . 0 5})$. Moreover, Waheed et al. ${ }^{(22)}$ reported in their study on thirty diabetic patients compared with 20 healthy subjects that serum MCP-1 level was significantly higher in diabetic patients than in control subjects $(\mathbf{4 8 . 8 7 \pm 1 2 . 3 4 5}$ vs. $38.8 \pm 8.994 \mathrm{ng} / \mathrm{ml}$ respectively, $\mathrm{p}<0.001$ ).

Our results showed that there was a strong positive correlation between the MCP-1 and the BMI in the old diagnosed diabetic group as they had the largest BMI among groups. This goes in agreement with the results of Waheed $\boldsymbol{e t}$ al. ${ }^{(22)}$ who found a significant positive correlation between MPC-1 and BMI in the patient group (r:0.717 and p: $\mathbf{0 . 0 0 3})$. This association can be explained by that MCP-1 has a direct role in the development of obesity. Yoshioka et al. ${ }^{(23)}$ reported that MCP-1- induced protein (MCPIP, a zinc finger protein) induced adipogenesis in 3T3- L1 cells independent of PPAR gamma activation ${ }^{(24)}$.

Significant positive correlations in both diabetic groups were found between the MCP-1 and total cholesterol, triglycerides and LDL, while a significant negative correlation was found between the MCP-1 and HDL. This result goes in similarity with Wang and Chen ${ }^{(21)}$ who reported that they found that the level of MCP-1 was positively correlated with LDL$\mathrm{C}$ and TC $(\mathbf{r}=322, \quad \mathrm{P}=005 ; \quad \mathrm{r}=333 ; \quad \mathrm{P}=003$, respectively) and the correlation was statistically significant. Although a tendency of positive correlations between uMCP-1 and TG was found $(\mathbf{r}=184, \quad P=111)$, a negative correlation between uMCP-1 and HDL-C was also found $(\mathbf{r}=-\mathbf{0 . 1 7 5}$, $\mathbf{P}=\mathbf{0 . 1 3 0}$ ) and the correlation did not achieve statistical significance.

Our results also showed a significant strong positive correlation between MCP-1 and both FBS and $\mathrm{HbA} 1 \mathrm{c}$ in the two diabetics groups. This result is in agreement with Waheed $\boldsymbol{e t}$ al. ${ }^{(22)}$ who found a positive highly significant correlation between MCP-1 and age, BMI, HbAlc, TGF- $\beta 1$, glucose and insulin ( $\mathbf{r}$ $=0.359, \mathrm{r}=0.717, \mathrm{r}=0.395, \mathrm{r}=0.217, \mathrm{r}=0.595$ and $\mathbf{r}=\mathbf{0 . 5 5 8}$ respectively, $\mathbf{P}<0.01)$ in patients 
complaining of DM type 2. Our result also showed that there was no significance difference between MCP-1 and Hypertension in both diabetic groups. These results go in agreement with Ishibashi $\boldsymbol{e t}$ al. ${ }^{(25)}$ who reported that MCP-1 was not a predictor for hypertension on their study.

Our results showed that serum MCP-1 was elevated in cases of the $3^{\text {rd }}$ group " old diagnosed diabetic patients" who was known to be suffering of diabetes complications where $9 / 27$ were suffering from diabetic nephropathy, 9/27 were suffering of diabetic retinopathy and the last $9 / 27$ were suffering of neuropathy" in percentage of $33.3 \%$ for all. Nevertheless, no significance was found between serum MCP-1 levels when compared in the $3^{\text {rd }}$ group between different diabetic complications. These result go in harmony with what was reported by Morita $\boldsymbol{e t}$ al. (26) that serum MCP-1 level was found to be higher in proliferative retinopathy patients than non-retinopathy and multiple regression analysis revealed that MCP-1 concentrations were significantly correlated with diabetic retinopathy $(\mathbf{P}=\mathbf{0 . 0 0 7})$ among clinical data including chronic complications.

\section{CONCLUSION}

The results of our study revealed that the MCP-1 level was increased in type 2 diabetic patients and significantly increased with the progression of diabetes complications as diabetic retinopathy, diabetic nephropathy and diabetic neuropathy. The MCP-1 level can be used as a predictor marker in early stage of diabetic complications in type 2 diabetic patients, as it showed significant positive correlation with the level of proteinuria. It showed a significant association with the incidence of retinopathy and neuropathy and also a significant positive correlation with the level of FBS and $\mathrm{HbA} 1 \mathrm{c}$.

\section{RECOMMENDATION}

We recommend further studies to understand the relation between the MCP-1 level and progression of diabetes complications.

\section{REFERENCES}

1. George L (2013): Induction of Vascular Insulin Resistance and Endothelin-1 Expression and Acceleration of Atherosclerosis by the Overexpression of Protein Kinase C- $\beta$ Isoform in the Endothelium. Circulation Research, 113: 418-427.

2. Li Y, Tucci M, Narain S et al. (2006): Urinary biomarkers in lupus nephritis. Autoimmun Rev., 5 (6): 383-8.

3. Dragomir E, Simionescu M (2006): Monocyte Chemoattractant Protein-1- a major contributor to the inflammatory process associated with diabetes. Arch Physiol Biochem., 112: 239-44.

4. Wang Q, Chen F (2009): Clinical significance and different levels of urinary monocyte chemoattractant protein- 1 in type 2 diabetes mellitus. Diabetes Res Clin Pract., 83(2):215-9.

5. Panee J (2012): Monocyte Chemoatractant Protein 1 (MCP-1) in Obesity and Diabetes. Cytokine, 60 (1): 112

6. Charo I, Taubman M (2004): Chemokines in the pathogenesis of vascular disease. Circ Res., 95: 858866

7. Zaica R (2014): MCP-1 (Monocyte chemotactic protein -1) and harpin molecules in inflammation processes Bio Med., 44 (7): 213-217

8. Ihm C, Park J, Hong S et al. (1998): A high glucose concentration stimulates the expression of monocyte chemotactic peptide- 1 in human mesangial cells. Nepheron., 79: 33-37.

9. Dragomir E, Manduteanu I, Calin M et al. (2008): High Glucose conditions induce upregulation of fractalkine and monocyte chemotactic protein-1 in human smooth muscle cells. Thromb Haemost., 100: 1155-65.

10. Luo $P$, Tan $Z$, Zhang $Z$ et al. (2008): Scutellarin isolated from Erigeron multiradiatus inhibits high glucose- mediated vascular inflammation. Yakugaku Zasshi., 128: 1293-9.

11. Shanmugam N, Reddy $M$, Guha $M$ et al. (2003): High glucose- induced expression of proinflammatory cytokine and chemokine genes in monocytic cells. Diabetes, 52: 1256-64.

12. Huber J, Kiefer F, Zeyda M et al. (2008): CC chemokine and $\mathrm{CC}$ chemokine receptor profiles in visceral and subcutaneous adipose tissue are altered in human obesity. J Clin Endocrinol Metab., 93: 3215-21.

13. Harman-Boehm I, Blüher M, Redel H et al. (2007): Macrophage infiltration into omental versus subcutaneous fat across different populations: effect of regional adiposity and the comorbidities of obesity. $\mathrm{J}$ Clin Endocrinol Metab., 92: 2240-7.

14. Catalán V, Gómez-Ambrosi J, Ramirez B et al. (2007): Proinflammatory cytokines in obesity: impact of type 2 diabetes mellitus and gastric bypass. Obes Surg., 17: 1464-74.

15. Breslin W, Johnston C, Strohacker K et al. (2012): Obese Mexican American children have elevated MCP-1, TNF-alpha, monocyte concentration, and dyslipidemia. Pediatrics, 129 (5): e1180-e1186.

16. Bose T, Alvarenga J, Tejero $M$ et al. (2009): Association of monocyte chemoattractant protein-1 with adipocyte number, insulin resistance and liver function markers. J Med Primatol., 38: 418-24.

17. Lee $\mathbf{Y}$, Lee $\mathbf{S}$, Jung $\mathbf{E}$ et al. (2010): Visceral adiposity and the severity of coronary artery disease in middleaged subjects with normal waist circumference and its relation with lipocalin-2 and MCP-1. Atherosclerosis, 213: 592-7.

18. World Health Organization WHO (2017): Obesity and overweight Fact sheet: WHO World Health Organization. Available from: http://www.who. int/mediacentre/ factsheets/fs311/en/.

19. Tilak P, Khashim Z, Kumpatla $S$ et al. (2010): Clinical significance of urinary Monocyte Chemoattract Protein 1 (uMCP-1) in Indian type 2 diabetic patients at different stages of diabetic 
nephropathy. International Journal of Diabetes Mellitus, 2: 15-19.

20. Agrawal P, Reddy V, Madaan H et al. (2014): Urban- rural differences in atherogenic dyslipidaemia (URDAD Study): a retrospective report on diabetic and non-diabetic subjects of Northern India. J Health Popul Nutr., 32 (3): 494-502.

21. Wang Q, Chen F (2009): Clinical significance and different levels of urinary monocyte chemoattractant protein-1 in type 2 diabetes mellitus. Diabetes Res Clin Pract., 83 (2): 215-9.

22. Waheed H, Khalil M, Fawzi S (2015): Evaluation of Monocyte Chemoattractant Protein-1 (MCP-1) in Type 2 Diabetes Mellitus. Int J Sci Eng Res., 6 (5): 791-797

23. Yoshioka K, Yoshida T, Kogure A et al. (2009): Monocyte chemoattractant protein-1 -2518 polymorphism is not associated with diabetic retinopathy in Japanese type 2 diabetes. Diabetes Metab Syndr: Clin Res Rev., 3: 166-168.

24. Pan Q, Yang X, Cheng Y et al. (2009): Angiotensin II stimulates $\mathrm{MCP}-1$ production in rat glomerular endothelial cells via NAD (P) $\mathrm{H}$ oxidase- dependent nuclear factor-kappa B signaling. NF- $\kappa \mathrm{B}$ in Ang IIinduced MCP-1 production. Brazilian Journal of Medical and Biological Research, 42: 531-536.

25. Ishibashi M, Hiasa $K$, Zhao $Q$ et al. (2004): Critical Role of Monocyte Chemoattractant Protein-1 Receptor CCR2 on Monocytes in Hypertension-Induced Vascular Inflammation and Remodeling. Circ Res., 94: 1203-1210.

26. Morita S, Ueyama M, Shimajiri Y et al. (2010): Circulating monocyte chemoattractant protein-1 links to diabetic retinopathy in type 2 diabetic patients without renal dysfunction. Diabetol Int., 1: 78-82. 